\title{
HUBUNGAN PENGAWASAN TERHADAP MOTIVASI KERJA KARYAWAN PADA CV. SYAILENDRA JAYA PALEMBANG
}

\author{
Akila *) \\ ABSTRAK
}

\begin{abstract}
Tujuan penelitian ini untuk mengetahui hubungan pengawasan terhadap motivasi kerja karyawan pada CV. Syailendra Jaya Palembang. Populasi penelitian seluruh karyawan yang berjumlah 30 orang, besar sampel yang diambil 30 orang, instrument dilakukan dengan cara validitas dan rehabilitas, objek penelitian bertempat Jalan Sudirman No. 172 Rt.002 Kelurahan 18 llir Kecamatan llir I Palembang, metode penelitian deskriptif kuantitatif, sumber data adalah primer dan sekunder, Teknik pengumpulan data dengan cara obsevasi, kuesioner, wawancara. Tehnik analisis data yaitu analisis regresi linier sederhana dan kolerasi. Hasil program SPSS, nilai koefisien regresi constant $=0,690$ dan koefisien regresi pengawasan $=0,870$. Sehingga regresi sederhana: $Y=0,690$ $+0,870 \mathrm{X} 1+\mathrm{e}$, dimana konstanta sebesar 0,690 menyatakan bahwa jika tidak ada pengawasan maka skor motivasi kerja adalah 0,690 . Koefesien regresi X1 sebesar 0,870 menyatakan bahwa setiap penambahan satu satuan skor pengawasan akan meningkat skor motivasi kerja sebesar 0,870. Dari perhitungan diperoleh nilai $R=0,875$ yang bearti bahwa varibel bebas yaitu pengawasan mempunyai hubungan yang sangat kuat terhadap variabel terikat yaitu motivasi kerja yang memiliki arah yang positif.

Hasil penelitian yang menunjukkan bahwa terdapat pengaruh yang signifikasi antara variabel pengawasan terhadap variabel motivasi kerja karyawan CV. Syailendra Jaya Palembang. Berarti semakin tinggi skor pengawasan, maka semakin tinggi pulah motivasi kerja karyawan. Artinya apabila pengawasa tinggi, maka motivasi kerja karyawan akan tinggi
\end{abstract}

Kata Kunci : Pengawasan, Motivasi Kerja

\section{PENDAHULUAN}

\section{A. Latar Belakang Masalah}

Setiap kegiatan yang dilakukan

baik dalam bentuk perusahaan maupun perseorangan mempunyai tujuan yang jelas. Dalam mencapai tujuan tersebut diperlukan perencanaan, pengawasan, sumber daya manusia.

Pada umumnya pengawasan ditujukan kepada manusia, karena manusialah yang melaksanakan kegiatan-kegiatan tersebut. Manusia mempunyai ide-ide, pikiran, pendapat apa yang telah dikerjakannya. Dalam suatu perusahaan seorang pimpinan perlu melakukan pengawasan terhadap bawahannya agar karyawan termotivasi berkerja dengan giat, semangat dan sungguh-sunguh, karena tampak adanya pengawasan kemungkinan akan terjadi penyelewengan, penyimpangan, dalam pelaksanaan pekerjaan. Dengan adanya pengawasan, dapat mengetahui sedini mungkin kesalahan dan kekeliruan, serta penyimpangan, sehingga dapat dilakukan perbaikan sebelum membawa dampak yang lebih besar.

Pengawasan bertujuan untuk mengamati, mengukur suatu kegiatan operasional dan hasil yang dicapai, juga menjaga tidak terjadinya kesalahan terhadap pekerjaan serta untuk mengetahui apakah suatu pekerjaan berjalan sesuai yang di rencanakan atau tidak. Sehingga hasil pekerjaan diperoleh secara berdaya guna dan berhasil guna. Menurut Handoko (2009), pengawasan adalah suatu usaha sistematis untuk menetapkan pekerjaan apa yang sudah dilaksanakan. Pengawasan berarti pengamatan dan pengukuran sesuatu kegiatan operasional dan hasil yang dicapai dibandingkan dengan sasaran dan standar yang telah ditetapkan sebelumnya. 
Motivasi bukanlah suatu yang diamati tetapi adanya sesuatu prilaku yang tampak seperti keinginan yang terdapat pada diri seseorang individu yang merangsang untuk melakukan pekerjaan. Oleh sebab itu, dapat dikatakan setiap prilaku manusia merupakan serangkaian kegiatan, inspirasi, semangat, dan dorongan untuk bekerja.

Motif dari diri sendiri murupakan cerminan dari motivasi yang baik dan terarah, sedangkan motif dari lingkungan kerja salah satunya adalah cerminan dari peraturan-peraturan organisasi atau perusahaan. Motivasi adalah suatu faktor yang mendorong seseorang untuk melakukan suatu aktivitas tertentu, oleh karena itu motivasi sering kali diartikan pula sebagai faktor pendorong perilaku seseorang. Sopiah (2008) Motivasi adalah keadaan dimana usaha dan kemauan keras seseorang kepada pencapaian hasil-hasil atau tujuan tertentu. Hasil-hasil yang dimaksud bisa berupa produktivitas, kehadiran atau prilaku kerja kreatif lainnya. Sedang Dorongan atau tenaga tersebut merupakann gerakan jiwa untuk berbuat sehingga motivasi tersebut merupkan tenaga yang menggerakan manusia untuk bertingkah laku di dalam perbuatan mempunyai tujuan tertentu. Sehingga motivasi penting dalam rangka mencapai tujuan seperti pemenuhan kebutuhan dan karier karyawan.

Berdasarkan pengamatan yang penulis lakukan di CV. Syailendra Jaya Palembang. Salah satu perusahaan yang bergerak dibidang pengadaan barang dan rupa-rupa usaha. Dalam hal motivasi kerja, karyawan masih belum bersemangat dalam melaksanakan pekerjaan dan tanggung jawab terhadap pekerjaan masih kurang. Keadaan ini terlihat lambatnya penyelesaian suatu pekerjaan yang seharurnya diselesaikan tepat waktu. Dalam hal pengawasan dilakukan dengan secara tidak langsung, artinya pengawasan dilakukan hanya dengan menerima laporan dalam bentuk tertulis tanpa memperhatikan

pelaksanaan pekerjaan secara langsung, dengan demikian karyawan tidak tervotivasi dalam bekerja. Selain itu pengawasan hanya dilakukan setelah terdapat hasil pekerjaan yang tidak memenuhi standar. Walaupun peraturan dibuat dengan baik, apabila pengawasan belum dilakukan dengan efektif maka motivasi kerja tidak tertaman dalam diri karyawan.

Berdasarkan uraian diatas, penulis tertarik melakukan penelitian dengan judul : "Hubungan Pengawasan Terhadap Motivasi Kerja Karyawan Pada CV. Syailendra Jaya Palembang".

\section{B. Rumusan Masalah}

Berdasarkan latar belakang ditas, maka dirumuskan masalah dalam penelitian ini : Apakah terdapat hubungan pengawasan terhadap motivasi kerja karyawan CV. Syailendra Jaya Palembang.

\section{Tujuan Penelitian}

Atas dasan permasalahan yang dikemukan di atas, maka penelitian ini bertujuan untuk mengetahui apakah terdapat hubungan pengawasan tarhadap motivasi kerja karyawan CV. Syailendra Jaya Palembang.

\section{Kontribusi Penelitian}

Hasil penelitian ini daharapkan bermanfaat:

1. Untuk memberikan sumbangan pemikiran dan perkembangan ilmu pengetahuan, khusunya yang berhubungan dengan peningkatan sumber daya manusia. 
2. Sebagai bahan masukan bagi pimpinan CV. Syailendra Jaya Palembang khususnya dalam upaya meningkatkan pengawasan dan motivasi kerja karyawan.

3. Melengkapi dan memperluas teori yang sudah diperoleh melalui penelitian lain sebelumnya dan menambah wawasan penulis dan peneliti lain dalam pengembangan ilmu pengetahuan.

\section{Tinjauan Pustaka}

\section{A. Defenisi Motivasi}

Fahmi (2012) motivasi adalah aktivitas prilaku yang bekerja dalam usaha memenuhi kebutuhan yang di inginkan.

Heidjrachman dan husnan (2009) motivasi adalah merupakan proses untuk mencoba mempengaruhi seseorang agar melakukan sesuatu yang kita inginkan.

Hasibuan (2011) motivasi adalah pemberian daya penggerak yang menciptakan kerja seseorang agar mereka mau bekerja sama, bekerja efektif, dan terintegrasi dengan segala daya upayanya untuk mencapai kepuasan.

Dari pendapat ahli disimpulkan bahwa motivasi yang menggerakkan manusia ke arah tujuan keahlian dalam mengarahkan karyawan perusahaan agar mau berkerja, sehingga keinginan karyawan dan tujuan perusahaan sekaligus tercapai.

Hasibuan (2011) bependapat tujuan motivasi di bagi 10 bagian sebagai berikut :

1. Meningkatkan moral dan kepuasan kerja pegawai.

2. Meningkatkan produktivitas kerja pegawai.

3. Mempertahankan kestabilan pegawai perusahaan.
4. Meningkatkan

kedisiplinan pegawai.

5. Mengefektifkan pengadaan pegawai.

6. Menciptakan suasana dan hubungan kerja kerja yang baik.

7. Meningkatka loyalitas, kreativitas, dan partisipasi pegawai.

8. Meningkatkan tingkat kesejahteraan pegawai.

9. Mempertinggi rasa tanggung jawab pegawai terhadap tugas-tugasnya.

10. Meningkatkan efisien penggunaan alat-alat pembantu.

Dari pendapat tersebut disimpulkan bahwa tujuan motivasi adalah untuk meningkatkan moral dan kepuasan, produktivitas, kesetabilan pegawai perusahaan, kedisiplinan pegawai, pengadaan pegawai, suasana dan hubungan yang baik, loyalitas, kreativitas, dan partisipasi pegawai, tingkat kesejahteraan pegawai, rasa tanggung jawab pegawai terhadap tugas-tugasnya, efisien penggunaan alat-alat pembantu.

\section{Jenis-jenis Motivasi}

Menurut Hasibuan (2011) jenisjenis motivasi dibagi 2 (dua) yaitu :

1. Motivasi positif adalah pemimpin memotivasi bawahan dengan memberikan hadiah kepada mereka yang berprestasi diatas prestasi standar.

2. Motivasi negatif yaitu pemimpin memotivasi bawahan dengan standar mereka akan mendapat hukuman.

Dari pendapat tersebut disimpulkan motivasi positif kinerja bawahan akan meningkat, karena pada umumnya manusia senang menerima yang baik-baik saja dan motivasi negatif bekerja bawahan dalam jangka waktu pendek akan meningkat karena mereka takut 
dihukum, tetapi untuk jangka waktu panjang dapat berakibat kurang baik.

\section{Faktor-Faktor yang Mempengaruhi Motivasi,}

Pada dasarnya banyak yang mempengaruhi faktor motivasi kerja, menurut Rivai (2006) sebagai berikut ;

1. Gaji yang adil dan kompetitif.

2. Insentif.

3. c.Lingkungan kerja.

4. Rasa aman dalam berkerja.

5. e.Penghargaan atas prestasi kerja.

6. f.Perilaku yang adil dari manajemen.

\section{B. Defenisi Pengawasan}

Trisnawati dan Saefullah (2006), pengawasan adalah suatu usaha sistematis untuk menetapkan standar pelaksanaan dengan tujuan-tujuan perencanaan, merancang sistem informasi umpan balik membandingkan kegiatan nyata dengan standar yang telah ditetapkan sebelumnya, menentukan dan mengukur penyimpangan serta pengambilan tindakan koreksi yang diperlukan untuk menjamin bahwa sumber daya perusahaan dipergunakan secara efektif dan efisien dalam pencapaian perusahaan.

Menurut Handoko (2009), pengawasan adalah suatu usaha sistematis untuk menetapkan pekerjaan apa yang sudah dilaksanakan.

Dari pendapat ahli disimpulkan bahwa pengawasan, seorang pimpinan tidak saja dituntut untuk mampu mengadakan perencanaan, pengawasan, pengorganisasian, pengendalian dan menggerakkan saja, akan tetapi harus mampu pulah melaksanakan pengawasan terhadap hasil pekerjaan yang dilakukan oleh bawahannya, supaya seorang pimpinan dapat mengetahui kesulitankesulitan dan hambatan-hambatan yang dihadapi bawahannya dalam pelaksanaan pekerjaan tersebut, sehingga dapat diambil suatu tindakan untuk memperbaikinya.

\section{Tujuan Pengawasan}

Menurut Manullang (2008) tujuan pengawasan adalah untuk mencegah atau memperbaiki kesalahankesalahan penyimpangan dan penyelewengan yang tidak sesuai dengan tugas dan tanggung jawab yang telah ditentukan. Dari pendapat ahli disimpulkan bahwa tujuan pengawasan bukan untuk mencari kesalahan terhadap orangnya, akan tetapi untuk mencari kebenaran terhadap hasil pekerjaan yang dilaksanakan dalam mencapai tujuan organisasi yang telah ditentukan.

\section{Cara-cara Pengawasan}

Menurut Manullang (2008) supaya pengawasan yang dilakukan seorang atasan efektif, maka harus terkumpul fakta-fakta ditangan pemimpin yang bersangkutan sebagai berikut :

1. Peninjauan Pribadi (personal inspection, personal observation) adalah mengawasi dengan jalan meninjau secara pribadi sehingga dapat dilihat pelaksanaan pekerjaan.

2. Pengawasan melalui laporan lisan (oral report) adalah pengawasan dilakukan dengan pengumpulan fakta-fakta melalui laporan lisan yang diberikan kepada bawahan.

3. Pengawasan melalui laporan tertulis (written report) adalah merupakan suatu pertanggung jawaban kepada atasan mengenai pekerjaanyang dilaksanakannya, sesuai dengan instruksi dan tugastugas yang diberikan atasan kepadanya.

4. Pengawasan melalui laporan kepada hal-hal bersifat khusus 
atau control by exception adalah suatu sistem pengawasan itu ditunjukan kepada soal-soal pengecualian yang merupakan pengawasan ini hanya dilakukan bila diterima laporan yang menunjukkan adanya peristiwaperistiwa yang istimewa.

Dari pendapat diatas disimpulkan bahwa cara pengawasan dapat dilakukan dengan meninjau secara pribadi, menerima laporan secara lisan dari bahawan, melalui laporan bentuk tertulis dan laporan yang bersifat khusu.

\section{Kerangka Pemikiran}

Secara ringkas kerangka pemikiran yang mendasari penelitian ini yaitu hubungan antara variabel bebas dan variable terikat

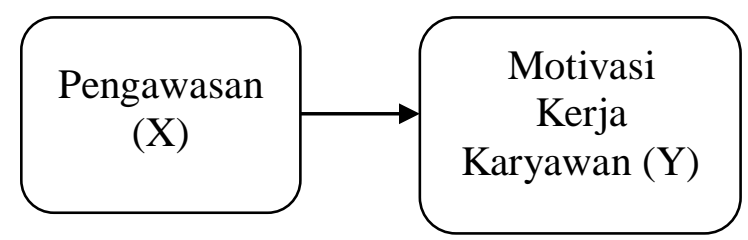

\section{Hipotesis Penelitian}

Berdasarkan kerangka pemikiran diatas, hopitesis yang akan diajukan dalam penelitian ini adalah :

Ho: Diduga tidak ada hubunga pengawasan terhadap motivasi kerja karyawan CV. Syailendra Jaya Palembang.

$\mathrm{Ha}$ : Diduga ada hubungan pengawasan terhadap motivasi kerja karyawan CV. Syailendra Jaya Palembang.

\section{Prosedur Penelitian \\ Populasi dan Sampel \\ Populasi Penelitian}

Pendapat Arikunto, (2010) populasi adalah keseluruhan subjek penelitian. Populasi diartikan sebagai wilayah generalisasi yang terdiri dari atas objek dan subjek yang mempunyai karakteristik tertentu yang ditetapkan oleh peneliti untuk di pelajari dan kemudian ditarik sesimpulan. Populasi dalam penelitian seluruh karyawan yang berjumlah 30 Orang. Dengan rincian karyawan tetap 12 orang dan karyawan tidak tetap 18 orang.

\section{Sampel Penelitian}

Sampel dalam penelitian ini mengacu pada pendapat Riduan dan Akdon (2010) apa bilah subjek kurang dari 100, maka lebih baik di ambil semua sehingga penelitian ini merupakan penelitian populasi. Maka penulis mengambil sampel keseluruhan karyawan yang berjumlah 30 orang.

\section{Objek Penelitian}

Objek penelitian bertempat Jalan Sudirman No. 172 Rt.002 Kelurahan 18 llir Kecamatan Ilir I Palembang.

\section{Metode Penelitian}

Dalam

penelitian ini menggunakan metode deskriptif kuantitatif. Menurut Sugiyono (2013) metode kuantitatif adalah suatu data yang berbentuk angka-angka. Metode penelitian yaitu meneliti hubungan 2 (dua) variabel yang menggunakan rumus-rumus statistik.

\section{Sumber Data dan Tehnik Pengumpulan Data Sumber Data}

Sumber data adalah primer dan sekunder.

\section{Tehnik Pengumpulan Data}

Teknik pengumpulan data dalam penelitian ini sebagai berikut ; 1) observasi adalah mengamati objek penelitian, 2) kuesioner, sebagai instrumen untuk mendapatkan data primer.yaitu dengan membuat daftar pertanyaan yang berisikan tentang 
cara pengawasan dan motivasi kerja karyawan. 3) wawancara, sebagai teknik langsung dengan objek penelitian.

\section{Variabel Penelitian dan Definisi Operasional Variabel Variabel Penelitian}

Menurut Sugiyono (2013)

Variabel adalah segala sesuatunya yang barbentuk apa saja yang di tetapkan oleh peneliti untuk di pelajari sehingga di peroleh infromasi. Maka yang menjadi variabel dalam penelitian yaitu variabel $X$ sebagai variabel bebas (pengawasan) dan variabel $Y$ sebagai variabel terikat (motivasi kerja karyawan)

\section{Definisi Operasional Variabel}

Defenisi operasional adalah suatu variabel dengan memberi arti atau spesifikasi kegiatan yang akan digunakan untuk mengukur varibel tersebut. Defenisi operasinal kemudian diuraiakan menjadi indikator yang digunakan pada setiap variabel sebagai berikut :

1. Motivasi adalah keadaan dimana usaha dan kemauan keras seseorang kepada pencapaian hasil-hasil atau tujuan tertentu. Hasil-hasil atau yang dimaksud bisa berupa produktivitas, kehadiran atau prilaku kerja kreatif lainnya (Sopiah, 2008). Indikator yang digunakan, meningkatkan pengetahuan dan keterampilan, lingkungan kerja, penghargaan atas prestasi kerja, tanggung jawab terhadap pekerjaan.

2. Pengawasan adalah suatu usaha sistematis untuk menetapkan standar pelaksanaan dengan tujuan-tujuan perencanaan, merancang sistem informasi umpan balik membandingkan kegiatan nyata dengan standar yang telah ditetapkan sebelumnya, menentukan dan mengukur penyimpangan serta pengambilan tindakan koreksi yang diperlukan untuk menjamin bahwa sumber daya perusahaan dipergunakan secara efektif dan efisien dalam pencapaian perusahaan (Trisnawati dan Saefullah, 2006). Indikator yang digunakan standar pelaksanaan pekerjaan, penilaian pekerjaan, perbandingan antara hasil pekerjaan dengan ukuran atau standar pekerjaan.

\section{Skala Pengukuran}

Pendapat Sugiyono (2013) skala liker adalah mengukur pendapat dan persepsi seseorang atau kelompok orang tentang penomena sosial sewaktu menanggapi pertanyaan dalam skala liker. Skala pengukuran terdiri dari kteria tanggapan terhadap pertanyaan dalam kusioner dengan pertanyaan sangat setuju (5), setuju (4), kurang setuju (3), tidak setuju (2) dan tidak setuju (1).

\section{Pengujian Instrumen Peneltian}

Pendapat Sugiyono instrument penelitian adalah sebelum digunakan sebagai alat pengumpulan data penelitian, terlebih dahulu dilakukan uji coba untuk menguji validitas dan rehabilitas.Pengumpulan data menggunakan kuisioner sehingga valitidas dan rehabilitas penelitian ditentukan oleh alat ukur yang digunakan. Hasil penelitian valid jika terdapat kesamaan antara data yang terkumpul dengan data yang sesunggunya pada objek yang diteliti, jika terdapat kesamaan data pada waktu yang berbeda dikatakan reliabel.

\section{F. Tehnik Analisis Data}

Dalam teknik analisis data yang dipergunakan dalam penelitian ini adalah analisis Analisis regresi linier sederhana, kolerasi. Analisis ini 
dugunakan untuk mengetahui seberapa kuatnya hubungan antara variable bebas terhadap variable terikat yaitu pengawasan terhadap motovasi kerja karyawan.

Dimana :

1. Analisis Regresi Linier Sederhana.

$$
\bar{Y}=\mathrm{a}+\mathrm{bx}
$$

Keterangan :

y : Motivasi kerja

a : Bilangan konstanta

b : Koefisien

$x$ : Pengawasan

$\mathrm{n}$ : Jumlah sampel

Untuk menghitung a dan b, digunakan persamaan :

$$
\begin{aligned}
& a=\frac{\sum Y-b \sum X}{n} \\
& b=\frac{n \sum X Y-\sum X \sum Y}{n \sum x^{2}-\left(\sum x\right)^{2}}
\end{aligned}
$$

2. Analisis Koefisien Korelasi.

$$
\text { Koefisien korelasi yang }
$$
digunakan untuk mengetahui hubungan antara variabel-variabel yang diteliti. Nilai koefisien korelasi ( $r$ ) berkisar antara -1 sampai +1 , yang dinyatakan dengan kriteria sebagai berikut :

a. Bila nilai $r=-1$, maka antara variable yang satu dengan variable yang lain terhadap hubungan negatif, maksudnya bila $X$ mengalami kenaikan maka nilai $Y$ akan mengalami penurunan demikian sebaliknya.

b. Bila nilai $r=0$, maka hubungan atara kedua variabel sangat lemah atau tidak terdapat hubungan sama sekali antara variable $X$ dan variable $\mathrm{Y}$.

c. Bila nila $r=+1$, maka kolerasi antara dua variable bersifat searah dengan kata lain kenaikan dan penurunan nilai $X$ terjadi bersamasama kenaikan atau penuruan nilai Y

Untuk mengetahui hubungan seberapa besar variabel bebas (X) terhadap variabel terikat (Y) dalam hasil penelitian, maka dihitung koefisien determiniasi $\left(R^{2}\right)$ dengan rumus :

$$
\mathrm{R}^{2}=\frac{b \sum x+b \sum b}{\sum y}
$$

Dimana :

$$
\begin{array}{ll}
R & : \text { Koefisien Determinasi } \\
r^{2} & : \text { Koefisien Korelasi }
\end{array}
$$

\begin{tabular}{|c|c|c|c|c|c|c|}
\hline \multirow{2}{*}{\multicolumn{2}{|c|}{ Model }} & \multicolumn{2}{|c|}{$\begin{array}{c}\text { Unstandardized } \\
\text { Coefficients }\end{array}$} & \multirow{2}{*}{$\begin{array}{c}\text { Standardized } \\
\text { Coefficients } \\
\text { Beta } \\
\end{array}$} & \multirow[b]{2}{*}{$t$} & \multirow[b]{2}{*}{ Sig. } \\
\hline & & $B$ & Std. Error & & & \\
\hline \multirow[t]{2}{*}{1} & (Constant) & 690 & ,348 & & 1,982 & 057 \\
\hline & Pengawas an (X) & ,870 & ,091 & ,875 & 9,560 &, 000 \\
\hline
\end{tabular}

\section{PEMBAHASAN}

A. Analisi Regresi

TABEL I

ANALISIS REGRESI PENGAWASAN DAN MOTIVASI KERJA

Coefficients

a. Dependent Variable: Motivasi Kerja (Y)

Berasarkan hasil perhitungan melaui bantuan program SPSS, dapat dilihat dari hasil perhitungan tabel 1 diatas diperoleh nilai koefisien regresi 
dimana constant $=0,690$ dan koefisien regresi pengawasan $=0,870$. Sehingga regresi sederhana dapat dituliskan sebagai berikut : $Y=0,690+$ $0,870 X_{1}+e$, dimana konstanta sebesar 0,690 menyatakan bahwa jika tidak ada pengawasan maka skor motivasi kerja adalah 0,690. Koefesien regresi $\quad X 1$ sebesar $\quad 0,870$ menyatakan bahwa setiap penambahan satu satuan skor pengawasan akan meningkat skor motivasi kerja sebesar 0,870.

\section{TABEL 2}

\section{ANALISIS KOEFISIEN KORELASI DAN DITERMINASI}

Model Summary

\begin{tabular}{|l|r|r|r|r|}
\hline Model & \multicolumn{1}{|c|}{$\mathrm{R}$} & R Square & $\begin{array}{r}\text { Adjusted } \\
\text { R Square }\end{array}$ & $\begin{array}{r}\text { Std. Error of } \\
\text { the Estimate }\end{array}$ \\
\hline 1 &, $875^{\mathrm{a}}$ &, 765 &, 757 &, 231495 \\
\hline
\end{tabular}

a. Predictors: (Constant), Pengawasan $(X)$

Koefisien korelasi ini untuk mengukur seberapa besar tingkat keeratan hubungan tang terjadi antara vairabel bebas dan variable terikat. Menurut Sugiyono (2013) nilai koefisen korelasi dapat diiterpretasikan.

Tabel 3

Interval Koefisien Korelasi Nilai r

\begin{tabular}{|c|c|}
\hline $\begin{array}{c}\text { Interval } \\
\text { Koefisien }\end{array}$ & Tingkat Hubungan \\
\hline $0,00-0,199$ & Sangat Rendah \\
\hline $0,20-0,399$ & Rendah \\
\hline $0,40-0,599$ & Sedang \\
\hline $0,60-0,799$ & Kuat \\
\hline $0,80-1,000$ & Sangat kuat \\
\hline
\end{tabular}

Berasarkan hasil perhitungan melaui bantuan program SPSS, dapat dilihat dari table 2 di atas diperoleh nilai $R=0,875$ yang bearti bahwa varibel bebas yaitu pengawasan mempunyai hubungan yang sangat kuat terhadap variable terikat yaitu motivasi kerja yang memiliki arah yang positif. Angka $\left(R^{2}\right)$ sebesar 0,765 . Hal ini bearti bahwa $76,5 \%$ variable motivasi kerja dapat dijelaskan atau dipengaruhi oleh variable pengawasan dalam model regresi yang dihasilkan. Sisa sebesar $(100 \%-76,5)=23,5$ dijelaskan oleh varibel-varibel lain yang tidak termasuk dalam penelitian ini atau error (e)

\section{B. Uji Hipotesis}

Pengujian hipotesis dimaksudkan untuk mengatahui apakah hipotesis penelitian yang dugunakan ditolak atau diterima pada tingkat signifikan tertentu. Pengujian ini untuk mengetahui ada tidaknya hubungan varibael bebas dan variable terikat. Dari hasil perhitungan table 1 diatas terlihat bahwa pada kolom signifikasi untuk baris pengawasan diperoleh 0,000 atau signifikan yang diperoleh lebeh kecil dari $\propto=0,05$, artinya $\mathrm{Ho}$ di tolak, Ha diterima. Hal ini dapat diartikan bahwa secara bersama-sama atau parsial variable pengawasan (X) terhadap motivasi kerja (Y), jadi dapat disimpulkan bahwa hipotesis penelitian ini yang menyatakan, variable pengawasan secara bersama-sama atau persial berhugungan terhadap motivasi kerja karyawan CV. Syailendra Jaya Palembang.

\section{KESIMPULAN DAN SARAN}

a. Kesimpulan

Berdasarkan hasil analisis pembahasan dan pengelolaan data yang dilakukan dalam penelitian ini dapat disimpulkan, terdapat hubungan yang sifnifikan antara varibel bebas yaitu pengawasan dan varibel terikat yaitu motivasi kerja karyawan $\mathrm{CV}$. Syailendra Jaya Palembang. Hal ini terlihat bahwa semakin tinggi skor pengawasan, maka semakin tinggi pulah motivasi kerja. Artinya apabila pengawasan 
tinggi, maka motivasi kerja karyawan akan tinggi.

b.Saran

Pengawasan dalam peruhasaan harus lebih ditingkatkan lagi, sehingga dapat mendorong semangat kerja karyawan. Motivasi kerja karyawan perlu ditingkatkan secara berkesinambungan dengan terus memperketat pengawasan, sehingga diharapkan dengan pengawasan yang tinggi terhadap karyawan akan meningkatkan motivasi kerja karyawan secara keseluruhan.

\section{DAFTAR PUSTAKA}

Arikunto,Suharsimi,2010.Prosedur Penelitian Suatu Pendekatan Praktek. Jakarta : Rikena Cipta.

Fahmi Ilham.2012. Manajemen Kepimpinan. Alfabeta : Bandung.

Handoko, T. Hani. 2009. Manajemen. Yogyakarta: BPFE.

Hasibuan, SP Malayu. 2011. Manajemen Sumber Daya Manusia. Jakarta: Bumi Aksara.

Manullang, M. 2008. Dasar-Dasar Manajemen. Yogyakarta: Gajah Mada

University Press.

Riduan dan Akdon. 2010. Rumus dan Data dalam Analisis Statistik. Alfabeta. Bandung

Rivai, Veithzal, 2006 Manajemen Sumber Daya Manusia. Jakarta :PT.Bumi Aksara

Saefullah dan Trisnawati. 2006. Pengantar Manajemen. Jakarta: Prenada Media Group.
Silalahi, Ulbert. 2008. Studi Tentang IImu Administrasi konsep, Teori, dan Dimensi. Bandung : Sinar Baru

Sugiyono. 2013. Metodologi Penelitian Kuantitatif Kualitatif. Alfabeta. Bandung.

Sopaih. 2008. Perilaku Organisasi. Jogyakarta : CV.Andi Offset

Samsudin Sadili. 2006. Perilaku Organisasi. Jogyakarta : CV.Andi Offset 